\title{
Involvement of NMDA and AMPA receptors in the antidepressant-like activity of antidepressant drugs in the forced swim test
}

\author{
Małgorzata Wolak ${ }^{1}$, Agata Siwek ${ }^{1}$, Bernadeta Szewczyk ${ }^{3}$, Ewa Poleszak ${ }^{4}$, \\ Andrzej Pilc ${ }^{2,3}$, Piotr Popik ${ }^{2}$, Gabriel Nowak ${ }^{1,3}$ \\ ${ }^{1}$ Department of Pharmacobiology, Faculty of Pharmacy, Jagiellonian University Medical College, Medyczna 9 , \\ PL 30-688 Kraków, Poland \\ ${ }^{2}$ Faculty of Health Sciences, Jagiellonian University Medical College, Michałowskiego 12, \\ PL 31-126 Kraków, Poland \\ ${ }^{3}$ Department of Neurobiology, Institute of Pharmacology, Polish Academy of Sciences, Smętna 12, \\ PL 31-343 Kraków, Poland \\ ${ }^{4}$ Department of Applied Pharmacy, Medical University of Lublin, Chodźki 1, PL 20-093 Lublin, Poland \\ Correspondence: Gabriel Nowak, e-mail: nowak@if-pan.krakow.pl
}

\begin{abstract}
:
Background: The involvement of glutamate system (particularly the NMDA and AMPA receptors) in the mechanism of antidepressant activity was demonstrated in preclinical and clinical studies.

Methods: In the present study, we investigated the effect of NMDA and AMPA receptors' ligands (agonists and antagonists) on the antidepressant-like activity of escitalopram, milnacipran, imipramine and reboxetine in the forced swim test in mice.

Results: Antidepressant activity (reduction in immobility time) of escitalopram and milnacipran but not of imipramine and reboxetine was antagonized by N-methyl-D-aspartate acid. CGP37849 (antagonist of the NMDA receptor) enhanced the antidepressant activity of all examined antidepressants. On the other hand, CX614 (a potentiator/positive allosteric modulator of the AMPA receptor) enhanced the antidepressant activity of imipramine and reboxetine but not of escitalopram and milnacipran in this test. NBQX (the AMPA receptor antagonist) did not influence the antidepressant activity of all tested agents.

Conclusions: The data indicate the complex interactions following the activation or blockade of the NMDA and AMPA receptors with antidepressant drugs. The general phenomenon is the enhancing effect of the NMDA receptor antagonism on the antidepressant activity. Moreover, is can be concluded that the activity of antidepressants with a serotonergic mechanism of action can be inhibited by NMDA activation, while antidepressants with a noradrenergic mechanism of action are dependent on AMPA receptor transmission.
\end{abstract}

Key words:

antidepressants, NMDA, AMPA, ligands, forced swim test, mice

\section{Introduction}

Several lines of evidence suggest the involvement of ionotropic AMPA and NMDA glutamate receptors in the mechanism of action of antidepressant drugs [13, 18]. This evidence is bidirectional in that both chronic treatment with antidepressants affects the function of glutamate receptors, and antagonists of NMDA receptors as well as positive allosteric modulators of AMPA 
receptors exert antidepressant-like effects [2, 10, 13, 18]. Some of the latter effects were also investigated in clinical experiments (e.g., [3, 9] see [15, 16, 22] for review). For instance, conventional antidepressants, such as fluoxetine, positively modulate AMPA receptors by the phosphorylation of the GluRl subunit [14], and have been shown also to alter the function of NMDA receptors, at neurochemical, molecular and behavioral levels [1]. In addition, an interaction between AMPA and NMDA ligands in the tests predictive for antidepressant-like action have been shown, as NBQX (an AMPA receptor antagonist) inhibits the activity of some NMDA receptor antagonists (ketamine and NR2B selective Ro 25-6981) [8].

While some data suggest that antidepressants alter the response of animals to antagonists and positive modulators of NMDA and AMPA [e.g., 11, 19], we decided to investigate the effects of activation and inhibition of glutamate ionotropic receptors on the antidepressant-like action of imipramine, milnacipran, escitalopram and reboxetine in the forced swim test in mice. These four antidepressants are considered to target serotonin/noradrenaline systems (imipramine, milnacipran), serotonin systems (escitalopram) and the noradrenaline system (reboxetine). The NMDA receptor dependence was assessed with the use of N-methyl-D-aspartatic acid (NMDA, agonist) and DL-/E/-amino-4-methyl-5-phosphono-3-pentenoic acid (CGP37849, antagonist). The AMPA receptor dependence was assessed with the use of 2,3-dihydroxy-6-nitro-7sulfamoylbenzo(f)-quinoxaline-2,3-dione (NBQX, antagonist) and 2,3,6a,7,8,9-hexahydro- $11 \mathrm{H}$-[1,4]dioxino[2,3g]pyrrolo[2,1-b][1,3]- benzoxazin-11-one (CX614, potentiator/positive allosteric modulator).

\section{Materials and Methods}

\section{Animals}

All procedures were approved by the Ethical Committee of the Jagiellonian University Medical College, Kraków. The experiments were carried out on adult male albino Swiss mice (25-30 g). The animals were housed under conditions with a constant temperature $\left(20-22^{\circ} \mathrm{C}\right)$, a controlled 12 : 12 light-dark cycle and free access to food and water. Each experimental group consisted of 6-12 animals. The experiments were carried out between 9:00 a.m. and 2:00 p.m.

\section{Drug administration}

NMDA (Sigma) and CGP 37849 (Ciba-Geigy, Basel) were administered $1 \mathrm{~h}$ before the test, NBQX (Tocris House, Bristol, UK) 30 min and CX614 (Cortex Pharmaceuticals, USA) $15 \mathrm{~min}$ before the test. Milnacipran (Mil, Sigma, USA), reboxetine (Rb, Sigma, USA) and escitalopram (Es, Adamed, Poland) were administred $1 \mathrm{~h}$ before the test. Imipramine (IMI, Sigma, USA) was administered ip $45 \mathrm{~min}$ before the test. All compounds were dissolved in $0.9 \%$ saline. Control animals received an ip injection of saline (vehicle). The volume of vehicles or drug solutions for ip administrations was $10 \mathrm{ml} / \mathrm{kg}$.

According to Ethical Committee demands, in order to avoid the unnecessary use of animals, we limited our research including animals treated only with NMDA, CGP37849, CX614 or NBQX, which we had examined previously in our laboratory conditions (e.g., [17]).

\section{Forced swim test}

The studies were carried out on mice according to the method of Porsolt et al. [12]. The mice were dropped individually into glass cylinders $(25 \mathrm{~cm}$ high, $10 \mathrm{~cm}$ diameter) filled with water $\left(23-25^{\circ} \mathrm{C}\right)$ to the height of $10 \mathrm{~cm}$. The animals were left in the cylinder for $6 \mathrm{~min}$. After the first $2 \mathrm{~min}$, the total duration of immobility was measured during a 4-min test period. The mouse was judged to be immobile when it remained floating passively in the water.

\section{Locomotor activity}

The locomotor activity of mice was measured with photoresistor activity box (circular cages, diameter $25 \mathrm{~cm}$, two light beams). The animals were placed individually in an actimeter for $5 \mathrm{~min}$. The number of crossings of the light beams by the mouse was recorded as the locomotor activity.

\section{Statistical analysis}

The obtained data were evaluated by the one-way or two-way analysis of variance (ANOVA) followed by Bonferroni's post-hoc test. All of the results are presented as the means \pm standard error of the mean $(\mathrm{SEM}), \mathrm{p}<0.05$ was considered as a statistically significant difference. 


\section{Results}

\section{Effect of joint administration of antidepres- sants and NMDA on immobility duration in the FST (Tab. 1)}

Imipramine $(30 \mathrm{mg} / \mathrm{kg})$ induced a significant reduction in the immobility time. NMDA $(75 \mathrm{mg} / \mathrm{kg})$ administered by itself had no effect on the immobility time, and did not significantly antagonize the effect induced by imipramine treatment. Two-way ANOVA revealed a significant effect of imipramine $[\mathrm{F}(1,28)$ $=14.06, \mathrm{p}=0.0008])$, no effect of NMDA $[\mathrm{F}(1,28)$ $=0.27, \mathrm{p}=0.6070]$ and no interaction $[\mathrm{F}(1,28)=$ $1.20, \mathrm{p}=0.2830]$.

Milnacipran $(2.5 \mathrm{mg} / \mathrm{kg})$ induced a significant reduction in the immobility time. NMDA $(75 \mathrm{mg} / \mathrm{kg})$ administered by itself had no effect on the immobility time, but significantly antagonized the effect induced by milnacipran treatment. Two-way ANOVA revealed a significant effect of milnacipran $[F(1,27)=37.51$, $\mathrm{p}<0.0001]$, no effect of NMDA $[\mathrm{F}(1,27)=1.79$, $\mathrm{p}=0.1919]$ and a significant interaction $[\mathrm{F}(1,27)=$ $20.42, \mathrm{p}=0.0001]$.

Escitalopram $(4 \mathrm{mg} / \mathrm{kg})$ induced a significant reduction in the immobility time. NMDA $(75 \mathrm{mg} / \mathrm{kg})$ significantly antagonized the reduction induced by escitalopram in the immobility time. One-way ANOVA $[\mathrm{F}(2,20)=10.30, \mathrm{p}=0.0008]$.

Reboxetine $(10 \mathrm{mg} / \mathrm{kg})$ induced a significant reduction in the immobility time. NMDA $(75 \mathrm{mg} / \mathrm{kg}) \mathrm{did}$ not significantly antagonize the reduction induced by reboxetine in the immobility time. One-way ANOVA $[\mathrm{F}(3,26)=14.90, \mathrm{p}<0.0001]$.

\section{Effect of joint administration of antidepressants and CGP37849 on immobility duration in the FST (Tab. 1)}

Imipramine $(15 \mathrm{mg} / \mathrm{kg})$ or CGP37849 (NMDA receptor antagonist at the glutamate site, $0.3 \mathrm{mg} / \mathrm{kg}$ ), administered by themselves had no effect on the immobility time, but administered together significantly re-

Tab. 1. Effect of joint administration of antidepressants and NMDA receptor ligands in the forced swim test in mice

\begin{tabular}{|c|c|c|c|}
\hline A & NMDA activation & B & NMDA blockade \\
\hline $\mathrm{NaCl}$ & $197.5 \pm 5.55(8)$ & $\mathrm{NaCl}$ & $204.6 \pm 6.63(10)$ \\
\hline Imi (30 mg/kg) & $134.3 \pm 11.2^{*}(8)$ & Imi (15 mg/kg) & $180.1 \pm 8.84(11)$ \\
\hline NMDA (75 mg/kg) & $190 \pm 8.24(7)$ & CGP $(0.3 \mathrm{mg} / \mathrm{kg})$ & $200.6 \pm 3.60(10)$ \\
\hline Imi + NMDA (30 mg/kg+75 mg/kg) & $155.3 \pm 19.1(9)$ & Imi + CGP (30 mg/kg + 0.3 mg/kg) & $160.6 \pm 14.4^{*}(8)$ \\
\hline $\mathrm{NaCl}$ & $211.1 \pm 4.19(8)$ & $\mathrm{NaCl}$ & $214.7 \pm 3.72(7)$ \\
\hline Mil (2.5 mg/kg) & $155.3 \pm 6.65^{\star}(8)$ & Mil $(1.25 \mathrm{mg} / \mathrm{kg})$ & $192.2 \pm 9.52(6)$ \\
\hline NMDA (75 mg/kg) & $194.4 \pm 4.59(7)$ & CGP $(0.3 \mathrm{mg} / \mathrm{kg})$ & $191 \pm 4.46(5)$ \\
\hline Mil + NMDA (2.5 mg/kg + 75 mg/kg) & $186.0 \pm 4.98^{\#}(8)$ & $\mathrm{Mil}+\mathrm{CGP}(1.25 \mathrm{mg} / \mathrm{kg}+0.3 \mathrm{mg} / \mathrm{kg})$ & $181.8 \pm 7.02^{*}(8)$ \\
\hline $\mathrm{NaCl}$ & $223.7 \pm 5.04(7)$ & $\mathrm{NaCl}$ & $231 \pm 2.89(6)$ \\
\hline Es $(4 \mathrm{mg} / \mathrm{kg})$ & $159.4 \pm 12.15^{\star}(8)$ & Es $(2 \mathrm{mg} / \mathrm{kg})$ & $219.8 \pm 8.34(6)$ \\
\hline Es + NMDA (4 mg/kg + 75 mg/kg) & $209.7 \pm 4.37^{\#}(7)$ & $\mathrm{Es}+\mathrm{CGP}(2 \mathrm{mg} / \mathrm{kg}+0.3 \mathrm{mg} / \mathrm{kg})$ & $198.3 \pm 10.06^{\star}(8)$ \\
\hline $\mathrm{NaCl}$ & $226.8 \pm 1.86(9)$ & $\mathrm{NaCl}$ & $223.9 \pm 4.30(8)$ \\
\hline $\mathrm{Rb}(10 \mathrm{mg} / \mathrm{kg})$ & $187.1 \pm 4.41^{*}(8)$ & $\mathrm{Rb}(5 \mathrm{mg} / \mathrm{kg})$ & $221.4 \pm 5.23(5)$ \\
\hline- & & CGP $(0.3 \mathrm{mg} / \mathrm{kg})$ & $223.3 \pm 5.92(6)$ \\
\hline $\mathrm{Rb}+\mathrm{NMDA}(10 \mathrm{mg} / \mathrm{kg}+75 \mathrm{mg} / \mathrm{kg})$ & $180.1 \pm 10.95^{*}(9)$ & $\mathrm{Rb}+\mathrm{CGP}(5 \mathrm{mg} / \mathrm{kg}+0.3 \mathrm{mg} / \mathrm{kg})$ & $167.2 \pm 10.28^{*}(10)$ \\
\hline
\end{tabular}

Results (immobility time) are expressed in seconds as the mean \pm SEM of $(n)$ numbers of animals. Abbreviations: Imi - imipramine, NMDA $\mathrm{N}$-methyl-D-aspartic acid, CGP - CGP 37849, Mil-milnacipran, Es - escitalopram, Rb-reboxetine. * $\mathrm{p}<0.05 \mathrm{vs}$. control (NaCl), ${ }^{\#} \mathrm{p}<0.05 \mathrm{vs}$. antidepressant alone (Bonferroni's post-hoc test) 
duced the immobility time. Two-way ANOVA revealed a significant effect of imipramine $[\mathrm{F}(1,35)$ $=13.76, \mathrm{p}=0.0007]$, no effect of CGP37849 [F $(1,35)=1.82, \mathrm{p}=0.1857]$ and no interaction $[\mathrm{F}$ $(1,35)=0.79, \mathrm{p}=0.3797]$.

Milnacipran $(1.25 \mathrm{mg} / \mathrm{kg})$ or CGP37849 (0.3 mg/ $\mathrm{kg}$ ) administered by itself had no effect on the immobility time, but administered together significantly reduced the immobility time. Two-way ANOVA revealed a significant effect of milnacipran $[\mathrm{F}(1,22)=$ 5.42, $\mathrm{p}=0.0295]$, effect of CGP37849 $[\mathrm{F}(1,22)=$ $6.25, \mathrm{p}=0.0204]$ and no significant interaction $[\mathrm{F}(1,22)=0.95, \mathrm{p}=0.3407]$.

Escitalopram $(2 \mathrm{mg} / \mathrm{kg})$ administered by itself had no effect on the immobility time, but administered together with CGP37849 $(0.3 \mathrm{mg} / \mathrm{kg})$ significantly reduced the immobility time. One-way ANOVA $[\mathrm{F}(2,17)=4.160, \mathrm{p}=0.0338]$.

Reboxetine $(5 \mathrm{mg} / \mathrm{kg})$ or CGP37849 $(0.3 \mathrm{mg} / \mathrm{kg})$ administered by themselves had no effect on the immobility time, but administered together significantly reduced the immobility time. Two-way ANOVA revealed no significant effect of reboxetine $[F(1,25)=$
11.95, $\mathrm{p}=0.5738]$, an effect of CGP37849 [F $(1,25)$ $=10.42, \mathrm{p}=0.0035]$ and a significant interaction $[\mathrm{F}(1,25)=10.01, \mathrm{p}=0.0041]$.

\section{Effect of joint administration of antidepressants and NBQX on immobility duration in the FST (Tab. 2)}

Imipramine $(30 \mathrm{mg} / \mathrm{kg})$ induced a significant reduction in the immobility time. NBQX, an AMPA receptor antagonist $(10 \mathrm{mg} / \mathrm{kg})$, did not influence the imipramine effect on the immobility time. One-way ANOVA $[F(2,17)=24.99, \mathrm{p}<0.0001]$.

Milnacipran $(2.5 \mathrm{mg} / \mathrm{kg})$ induced a significant reduction in the immobility time. NBQX $(10 \mathrm{mg} / \mathrm{kg})$ did not influence the milnacipran's effect on the immobility time. One-way ANOVA $[\mathrm{F}(2,23)=7.516, \mathrm{p}=0.0031]$.

Escitalopram $(4 \mathrm{mg} / \mathrm{kg})$ induced a significant reduction in the immobility time. NBQX $(10 \mathrm{mg} / \mathrm{kg})$ did not influence the citalopram's effect on the immobility time. One-way ANOVA $[\mathrm{F}(2,21)=9.874, \mathrm{p}<$ $0.0009]$.

Tab. 2. Effect of joint administration of antidepressants and AMPA receptor ligands in the forced swim test in mice

\begin{tabular}{|c|c|c|c|}
\hline A & AMPA blockade & B & AMPA activation \\
\hline $\mathrm{NaCl}$ & $225.1 \pm 2.08(8)$ & $\mathrm{NaCl}$ & $226.5 \pm 3.53(8)$ \\
\hline Imi (30 mg/kg) & $178.8 \pm 12.34^{\star}(6)$ & Imi (15 mg/kg) & $207.0 \pm 5.475(9)$ \\
\hline Imi + NBQX (30 mg/kg + 10 mg/kg) & $155 \pm 6.58^{\star}(6)$ & Imi + CX (15 mg/kg + 1 mg/kg) & $191.6 \pm 6.27^{\star}(10)$ \\
\hline $\mathrm{NaCl}$ & $202.5 \pm 6.28(11)$ & $\mathrm{NaCl}$ & $209.7 \pm 6.14(6)$ \\
\hline Mil (2.5 mg/kg) & $149.5 \pm 17.62^{\star \star}(6)$ & Mil $(1.25$ mg/kg) & $217.3 \pm 5.73(6)$ \\
\hline - & & $C X(1 \mathrm{mg} / \mathrm{kg})$ & $196.7 \pm 7.30(6)$ \\
\hline Mil + NBQX (2.5 mg/kg + 10 mg/kg) & $158.3 \pm 11.12^{\star}(9)$ & $\mathrm{Mil}+\mathrm{CX}(1.25 \mathrm{mg} / \mathrm{kg}+1 \mathrm{mg} / \mathrm{kg})$ & $203.7 \pm 15.94(10)$ \\
\hline $\mathrm{NaCl}$ & $226.5 \pm 3.53(8)$ & $\mathrm{NaCl}$ & $231 \pm 2.89(6)$ \\
\hline Es (4 mg/kg) & $196.3 \pm 6.54^{\star \star}(8)$ & Es (2 mg/kg) & $219.8 \pm 8.34(6)$ \\
\hline $\mathrm{Es}+\mathrm{NBQX}(4 \mathrm{mg} / \mathrm{kg}+10 \mathrm{mg} / \mathrm{kg})$ & $205.3 \pm 4.24^{*}(8)$ & $E s+C X(2 \mathrm{mg} / \mathrm{kg}+1 \mathrm{mg} / \mathrm{kg})$ & $217.7 \pm 2.14(6)$ \\
\hline $\mathrm{NaCl}$ & $221.8 \pm 3.34(8)$ & $\mathrm{NaCl}$ & $217 \pm 3.39(8)$ \\
\hline $\mathrm{Rb}(10 \mathrm{mg} / \mathrm{kg})$ & $187.1 \pm 4.41^{*}(8)$ & $\mathrm{Rb}(5 \mathrm{mg} / \mathrm{kg})$ & $202.8 \pm 4.85(8)$ \\
\hline- & & $\mathrm{CX}(1 \mathrm{mg} / \mathrm{kg})$ & $207.8 \pm 8.32(6)$ \\
\hline $\mathrm{Rb}+\mathrm{NBQX}(10 \mathrm{mg} / \mathrm{kg}+10 \mathrm{mg} / \mathrm{kg})$ & $182.6 \pm 11.64^{\star \star}(8)$ & $\mathrm{Rb}+\mathrm{CX}(5 \mathrm{mg} / \mathrm{kg}+1 \mathrm{mg} / \mathrm{kg})$ & $184.7 \pm 8.03^{*}(12)$ \\
\hline
\end{tabular}

Results (immobility time) are expressed in seconds as the mean \pm SEM of ( $\mathrm{n}$ ) numbers of animals. Abbreviations: Imi - imipramine, NBQX 2,3-dihydroxy-6-nitro-7-sulfamoylbenzo(f)-quinoxaline-2,3-dione, CX - CX 614, Mil - milnacipran, Es - escitalopram, Rb - reboxetine. ${ }^{*} \mathrm{p}<0.05 ;{ }^{* *} \mathrm{p}<0.01$ vs. control ( $\left.\mathrm{NaCl}\right)$ (Bonferroni's post-hoc test) 
Reboxetine $(10 \mathrm{mg} / \mathrm{kg})$ induced a significant reduction in the immobility time. NBQX $(10 \mathrm{mg} / \mathrm{kg})$ did not influence the reboxetine's effect on the immobility time. One-way ANOVA $[\mathrm{F}(2,21)=8.272, \mathrm{p}=0.0022]$.

\section{Effect of joint administration of antidepressants and CX614 on immobility duration in the FST (Tab. 2)}

Imipramine $(15 \mathrm{mg} / \mathrm{kg})$ did not induce a significant reduction in the immobility time. Combined treatment of imipramine and CX614, an AMPA receptor potentiator, induced a significant reduction in the immobility time. One-way ANOVA $[\mathrm{F}(2,24)=10.15 ; \mathrm{p}=$ 0.0006].

Milnacipran $(1.25 \mathrm{mg} / \mathrm{kg})$ administered by itself or together with CX614 $(1 \mathrm{mg} / \mathrm{kg})$ had no effect on the immobility time. Two-way ANOVA revealed no significant effect of milnacipran $[\mathrm{F}(1,24)=0.33, \mathrm{p}=$ 0.5738], no effect of CX614 [F $(1,24)=1.07, \mathrm{p}=$ $0.3118]$ and no significant interaction $[\mathrm{F}(1,24)=$ $0.00, \mathrm{p}=0.9806]$.

Escitalopram $(2 \mathrm{mg} / \mathrm{kg})$ administered by itself or together with CX614 $(1 \mathrm{mg} / \mathrm{kg})$ had no effect on the immobility time. One-way ANOVA $[\mathrm{F}(2,17)=1.344$; $\mathrm{p}=0.2871]$.

Reboxetine $(5 \mathrm{mg} / \mathrm{kg})$ or CX614 $(1 \mathrm{mg} / \mathrm{kg})$ administered by itself had no effect on the immobility time. Combined treatment of reboxetine and CX614 induced a significant reduction in the immobility time. Two-way ANOVA revealed a significant effect of reboxetine $[\mathrm{F}(1,29)=9.05, \mathrm{p}=0.0054, \mathrm{CX} 614$ $\mathrm{F}(1,29)=5.13, \mathrm{p}=0.0312]$ and no interaction $[\mathrm{F}(1,29)=0.86, \mathrm{p}=0.3622]$.

\section{Effect of antidepressants, NMDA and AMPA ligands on spontaneous locomotor activity in mice}

The examined treatment combinations of agents did not significantly influence the locomotor activity of mice (data not shown).

\section{Discussion}

The present data both confirm and extend the previous research on the interaction between antidepres- sant drugs and different sites of the NMDA receptor complex as well as interaction with AMPA receptors in the antidepressant-like activity in the FST in mice. Thus, the present data indicate that activation of NMDA receptors (by NMDA administration) attenuated the antidepressant activity of escitalopram and milnacipran (selective serotonin and serotonin/noradrenaline uptake inhibitors, respectively) but not that of imipramine or reboxetine (a non-selective serotonin/noradrenaline reuptake inhibitor with an affinity for receptors (adrenergic, histaminergic, e.g., [21]) and selective noradrenaline uptake inhibitors, respectively) (Tab. 3). This extends our previous report [11] which demonstrated the ability of D-serine (a coagonist at the NMDA receptor [20]) to antagonize the antidepressant activity of imipramine, fluoxetine and reboxetine in the FST in mice. Together, the data may indicate that both the activation of glutamate (NMDA) and glycine (D-serine) sites of the NMDA receptor complex is important for the antidepressant activity of antidepressants in this test. Moreover, the complex interaction of antidepressants with NMDA receptors is further demonstrated by showing the ability of the NMDA receptor antagonist, acting at the glutamate site (CGP37849) to enhance the antidepressant activity of all the drugs tested here (Tab. 3). On the other hand, the glycine site antagonists (L-701,324 and D-cycloserine) enhanced the antidepressant action of serotonin (imipramine and fluoxetine) but not the noradrenaline (reboxetine) uptake inhibitors [11]. These results clearly indicated the importance of the site in antagonizing the NMDA receptors in order to

Tab. 3. Complex interaction between agonists and antagonists of NMDA and AMPA receptors and four antidepressants with a different profile of action in the forced swim test in mice

\begin{tabular}{lcccc}
\hline & $5-\mathrm{HT}$ & $5-\mathrm{HT} / \mathrm{NA}$ & $5-\mathrm{HT} / \mathrm{NA}$ & $\mathrm{NA}$ \\
\cline { 2 - 5 } & Escitalopram & Milnacipran & Imipramine & Reboxetine \\
\hline $\begin{array}{l}\text { NMDA } \\
\text { activation }\end{array}$ & $\downarrow$ & $\downarrow$ & - & - \\
NMDA & $\uparrow$ & $\uparrow$ & $\uparrow$ & $\uparrow$ \\
blockade & & & & \\
$\begin{array}{l}\text { AMPA } \\
\text { activation }\end{array}$ & - & - & $\uparrow$ & $\uparrow$ \\
AMPA & - & - & - & - \\
blockade & & & & \\
\hline
\end{tabular}

Arrows indicate the potentiation $(\uparrow)$ and inhibition $(\downarrow)$ of the antidepressant-like effect; the "-" symbol indicates no effect 
affect the antidepressant activity of antidepressants in the FST.

The second issue in the present report is the involvement of the AMPA receptor in the antidepressant activity of antidepressants in the FST test in mice. The AMPA receptor antagonist (NBQX) did not influence the antidepressant action of any of the examined antidepressants, although a potentiator/positive allosteric modulator of this receptor (CX614) enhanced this activity of imipramine and reboxetine yet not of escitalopram or milnacipran (Tab. 3). The involvement of the AMPA receptor in the mechanism of antidepressants was indicated previously (e.g., $[4,18])$ and particularly in the antidepressant action of the NMDA receptor antagonists: ketamine, MK-801 and Ro256981 [8] but not of CGP37849 [5]. Similarly to the data presented here, Maeng et al., [8] did not demonstrate any effect of NBQX on the antidepressant action of imipramine in the FST in mice.

Based on our current and previous results [11] a form of relationship between the serotoninergic/ noradrenergic antidepressants and glutamate site of the NMDA (and possible AMPA) receptors in the FST seems to emerge. Poleszak et al. [11] demonstrated that the antidepressant activity of drugs with the serotonergic (yet not noradrenergic) mechanism of action was enhanced by the antagonists of the glycine site of the NMDA receptor, which was supported by Kaster et al. [6] study (enhancement of imipramine effect by administration of MK-801, an ion channel blocker). Here, an antagonist of the glutamate site at the NMDA receptor enhanced the antidepressant activity of all of the used antidepressants (both the selective serotonin and the selective noradrenaline uptake inhibitors). Moreover, it was reported [11] that the NMDA receptor activation by D-serine (acting at the glycine site) antagonized the activity of antidepressants with both the serotonergic and adrenergic mechanisms of action in the FST, while here the NMDA receptor activation through the glutamate site (by NMDA) antagonized only selective serotonin (and serotonin/noradrenaline) uptake inhibitors, and not the selective noradrenaline reuptake inhibitor (reboxetine) or a non-selective inhibitor (imipramine). It can be speculated that the obvious noradrenergic pharmacological mechanism of reboxetine and desipramine (the metabolite of imipramine and a potent NA-reuptake inhibitor) may overwhelm the serotonergic component of imipramine, hence the resistance to the NMDA activation. Conversely, the serotonergic mechanisms involved in the action of escitalopram and milnacipran may be important enough for their antidepressant activity to be dampened by NMDA stimulation.

It should be mentioned also that antidepressant activity of tianeptine (the serotonin uptake potentiator) in the FST in mice was antagonized by D-serine and NBQX administration, which indicates the dependency of this antidepressant effect on NMDA and/or AMPA transmission [19]. In view of all the studies, the inhibition or potentiation of serotonin uptake has no significance of NMDA-dependence of antidepressant activity but may be important in the AMPA relationship.

The role of AMPA receptors in the activity of antidepressants in the FST seems to be less important since the blockade of this receptor by NBQX did not affect the antidepressant activity of any of the drugs used here. However, the enhancement of antidepressant action by an AMPA receptor potentiator (CX614) was demonstrated for antidepressants such as imipramine and reboxetine; the effectiveness of which was not antagonized by NMDA receptor activation. It should be mention that the other AMPA receptor potentiator LY 392098 enhances antidepressant-like activity of imipramine or selective serotonin /noradrenaline uptake inhibitors (fluoxetine, citalopram, duloxetine, nisoxetine) [7].

The data indicate the complex interactions following the activation or blockade of the NMDA and AMPA receptors with antidepressant drugs. The general phenomenon is the enhancing effect of the NMDA receptor antagonism on the antidepressant activity. Moreover, is can be concluded that the activity of antidepressants with a serotonergic mechanism of action can be inhibited by NMDA activation, while antidepressants with a noradrenergic mechanism of action are dependent on AMPA receptor transmission.

\section{Acknowledgments:}

This study was supported by the statutory funds of Jagiellonian University Medical College, Kraków, Poland. The authors thank Adamed (Poland) for the generous gift of escitalopram and Cortex Pharmaceuticals (USA) for CX 614.

\section{References:}

1. Ampuero E, Rubio FJ, Falcon R, Sandoval M, DiazVeliz G, Gonzalez RE, Earle N et al.: Chronic fluoxetine treatment induces structural plasticity and selective 
changes in glutamate receptor subunits in the rat cerebral cortex. Neuroscience, 2010, 169, 98-108.

2. Barbon A, Caracciolo L, Orlandi C, Musazzi L, Mallei A, La Via L, Bonini D et al.: Chronic antidepressant treatments induce a time-dependent up-regulation of AMPA receptor subunit protein levels. Neurochem Int, 2011, 59, 896-905.

3. Berman RM, Cappiello A, Anand A, Oren DA, Heninger GR, Charney DS, Krystal JH: Antidepressant effects of ketamine in depressed patients. Biol Psychiatry, 2000, 47, 351-354.

4. Bleakman D, Alt A, Witkin JM: AMPA receptors in the therapeutic management of depression. CNS Neurol Disord Drug Targets, 2007, 6, 117-126.

5. Dybała M, Siwek A, Poleszak E, Pilc A, Nowak G: Lack of NMDA-AMPA interaction in antidepressant-like effect of CGP 37849, an antagonist of NMDA receptor, in the forced swim test. J Neural Transm, 2008, 115, $1519-1520$.

6. Kaster MP, Machado DG, Santos ARS, Rodrigues ALS: Involvement of NMDA receptors in the antidepressantlike action of adenosine. Pharmacol Rep, 2012, 64, 706-713.

7. Li X, Witkin JM, Need AB, Skolnick P: Enhancement of antidepressant potency by a potentiator of AMPA receptors. Cell Mol Neurobiol, 2003, 23, 419-430.

8. Maeng S, Zarate CA Jr, Du J, Schloesser RJ, McCammon J, Chen G, Manji HK: Cellular mechanisms underlying the antidepressant effects of ketamine: role of $\alpha$-amino-3-hydroxy-5-methylisoxazole-4-propionic acid receptors. Biol Psychiatry, 2008, 63, 349-352.

9. Nations KR, Dogterom P, Bursi R, Schipper J, Greenwald S, Zraket D, Gertsik L et al.: Examination of Org 26576, an AMPA receptor positive allosteric modulator, in patients diagnosed with major depressive disorder: an exploratory, randomized, double-blind, placebo-controlled trial. J Psychopharmacol, 2012, 26, 1525-1539.

10. Paul IA, Nowak G, Layer RT, Popik P, Skolnick P: Adaptation of the NMDA receptor complex following chronic antidepressant treatments. J Pharmacol Exp Ther, 1994, 269, 95-102.

11. Poleszak E, Wróbel A, Szewczyk B, Socała K, Kasperek R, Blicharska E, Nowak G, Wlaź P: Involvement of NMDA receptor complex in the anxiolytic-like effects of chlodiazepoxide in mice. J Neural Transm, 2011, 118, $857-864$.
12. Porsolt RD, Bertin A, Jalfre M: Behavioural despair in mice: a primary screening test for antidepressants. Arch Int Pharmacodyn, 1977, 229, 327-336.

13. Skolnick P, Popik P, Trullas R: Glutamate-based antidepressants: 20 years on. Trends Pharmacol Sci, 2009, 30, 563-569.

14. Szegedi V, Juhász G, Zhang X, Barkóczi B, Qi H, Madeira A, Kapus G et al.: Tianeptine potentiates AMPA receptors by activating CaMKII and PKA via the p38, p42/44 MAPK and JNK pathways. Neurochem Int, 2011, 59, 1109-1122.

15. Szewczyk B, Pałucha-Poniewiera A, Poleszak E, Pilc A, Nowak G: Authors' response: The differences in AMPA receptor dependence on antidepressant-like activity. Expert Opin Investig Drugs, 2012, 21, 584-585.

16. Szewczyk B, Pałucha-Poniewiera A, Poleszak E, Pilc A, Nowak G: Investigational NMDA receptor modulators for depression. Expert Opin Investig Drugs, 2012, 21, 91-102.

17. Szewczyk B, Poleszak E, Sowa-Kućma M, Wróbel A, Slotwiński S, Listos J, Wlaź P et al.: Involvement of NMDA and AMPA receptors in the antidepressant-like activity of zinc in the forced swim test. Amino Acids, 2010, 39, 205-217.

18. Witkin JM, Li X: New approaches to the pharmacological management of major depressive disorder. Adv Pharmacol, 2009, 57, 347-379.

19. Wlaź P, Kasperek R, Wlaź A, Szumiło M, Woźniak M, Wróbel A, Nowak G, Poleszak E: The NMDA and AMPA receptors are involved in the antidepressant-like activity of tianeptine in the forced swim test. Pharmacol Rep, 2011, 63, 1526-1532.

20. Wolosker H: NMDA receptor regulation by D-serine: new findings and perspectives. Mol Neurobiol, 2007, 36, 152-164.

21. Wong DT, Threlkeld PG, Best KL, Bymaster FP: A new inhibitor of norepinephrine uptake devoid of affinity for receptors in rat brain. J Pharmacol Exp Ther, 1982, 222, 61-65.

22. Yang C, Zhou W, Li X, Yang J: A bright future of researching AMPA receptor agonists for depression treatment. Expert Opin Investig Drugs, 2012, 21, 583-584.

Received: January 29, 2013; in the revised form: March 13, 2013; accepted: March 14, 2013 